\title{
SKILLS NEED OF BUSINESS EDUCATORS \\ FOR UTILISATION OF SYNCHRONOUS INSTRUCTIONAL STRATEGY IN TEACHING BUSINESS EDUCATION COURSES IN COLLEGES OF EDUCATION IN SOUTH-SOUTH NIGERIA
}

\author{
Nsini A. Akpan', \\ Uduonyi O. Eminue ${ }^{2 i}$, \\ Juliet O. Onyebueke², \\ Dominic E. Ogbang ${ }^{2}$ \\ ${ }^{1} \mathrm{PhD}$, Department of Business Education, \\ Faculty of Education, \\ University of Uyo, \\ Uyo, Akwa Ibom State, \\ Nigeria \\ ${ }^{2}$ Department of Business Education, \\ Faculty of Education, \\ University of Uyo, \\ Uyo, Akwa Ibom State, \\ Nigeria
}

\begin{abstract}
:
The main purpose of the study was to determine skills need of Business Educators for utilisation of synchronous instructional strategy in teaching Business Education courses in Colleges of Education in South-South Nigeria. Three specific objectives and three research questions were raised, while three hypotheses were formulated to guide this study. This study adopted a descriptive survey research design. The population of the study was 276 respondents made up of 164 Business Educators and 112 Computer Education lecturers from 10 State Colleges of Education in South-South Nigeria. The sample of the study was 163 respondents made up of 97 Business Educators and 66 Computer Education lecturers from 10 State Colleges of Education in South-South Nigeria. Convenient sampling technique was adopted to select respondents for the study. The researcher developed instrument titled Skills Need for Utilisation of Synchronous Instructional Strategy Questionnaire (SNUSIS) was used to obtain data for the study. The instrument was face validated by three research experts in University of Uyo, Akwa Ibom State, Nigeria. The internal consistency reliability of the instrument was determined using Cronbach Alpha which yielded a coefficient of 0.81 . The data collected were analysed using Mean and Improvement Need Index to answer the research questions, while hypotheses were tested using t-test at 0.05 level of significance. The results revealed
\end{abstract}

'Correspondence: email eminueuduonyi@yahoo.com 
that there is no significant difference in the Mean rating of Computer Education Lecturers and Business Educators in word processing skills need for utilisation of synchronous instructional strategy in teaching Business Education courses in Colleges of Education in South-South Nigeria. The findings also revealed that there is a significant difference between the Mean rating of Computer Education Lecturers and Business Educators in spreadsheet and PowerPoint skills need for utilisation of synchronous instructional strategy in teaching Business Education courses in Colleges of Education in South-South Nigeria. It is therefore recommended that management of Colleges of Education should provide opportunity for Business Educators to undertake more training on word processing, spreadsheet and PowerPoint through Seminars, workshops and conferences to enhance their ability to utilise synchronous instructional strategy in teaching Business Education courses in Colleges of Education in South-South Nigeria.

Keywords: business educators; synchronous instructional strategy; business education courses

\section{Introduction}

The abundance of natural resources in any nation does not in itself make it to be ranked among the developed countries; rather it is the specialised skills, competence and ability possessed by its populace which can be harnessed to utilise these resources. Nigeria as a developing nation needs a comprehensive functional education that will impart and impact the right knowledge, skills and attitudes as well as stir up the productive potentials of the citizenry to achieve self-reliance. Perhaps, Etifit, Eminue and Udoh (2016) noted that the higher educational programmes in Nigeria had fallen short of expectations, and as a result, many of the graduates of these institutions lack basic skills required by the labour market. In this rapidly changing world, the quest for self-reliance through education has always been the desire of many nations, especially in the present face of global economic challenges occasioned by the outbreak of corona virus (COVID19) pandemic. Projections by experts suggested that many countries of the world were heading towards the worst economic recession before the end of the year 2020 was true. This had triggered many countries of the world to re-evaluate their position and question their roles as nations and consider possible options for quick recovery from the pending economic recession. One of these options is the use of emerging information and communication technology (ICT) tools in Business Education in Nigeria, and the training of teachers to acquire the basic skills for utilization of synchronous instructional strategy in teaching of Business Education courses, which could be seen as investing in human capital.

Business Education is one of the fundamental factors of sustainable development of any country. Etifit et al. (2016) described Business Education is an aspect of Business Education programme that gives training and imparts necessary skills that will provide 
the recipients with the intellectual and professional background, adequate for their assignment and makes the recipients adaptable to changing situations in the world of work. Akpan and Eminue (2020) described Business Education as education responsible for equipping students with skills, attributes, knowledge and behavior required for teaching, entrepreneurship, administrative and clerical work. Asuquo (2016) saw Business Education as consisting of training for office occupational opportunities, teaching and entrepreneurship, hence a trained Business Educator assumes different roles.

Business Educator in Colleges of Education in the context of this study is used to refer to a lecturer in the department of Business Education who is responsible for teaching and learning of business skills, knowledge and attitude. It is the duty of Business Educator to effectively implement Business Education curriculum through effective teaching. On the other hand, Mba (2019) observed that the computer education lecturers are trained in pedagogical areas of computer science and are charged with the responsibilities of imparting knowledge, skills and attitude of computer science to students in the Colleges of Education. Asuquo and Usip (2016) noted that a Business Educators are trained professionally in a teachers' training college or faculty of education in the University or similar institutions that engage in business teacher education programme, while the computer education lecturers are trained in computer application/packages in different higher institutions of learning where they obtain various qualifications. Therefore, due to background knowledge and training, computer education lecturers are adjudged to be more competent in computer aided instruction than their colleague in Business Education. Hence, Computer Education lecturers are used in this study as expert to provide benchmark for the assessment of Business Educators performance to determine their skills need for utilization of synchronous instructional strategy.

Synchronous learning involves the exchange of ideas and information with one or more participants either in the same location or different places at the same time using ICT facilities (Eminue, Garba \& Njoku, 2020). LeShea (2013) described synchronous learning as learning that takes place simultaneously in real-time. Learners attend class at a scheduled time either in a traditional classroom or a course delivered via the web using various technologies. It facilitates efficient education and provides both students and lecturers with various ways of networking and sharing and collaborating in real-time (Higley, 2013). The rapid evolution of science and technology has made it that ICT facilities are found everywhere in our society, ranging from the simple technologies like mobile phones, digital camera, portable media players, podcasting, videoconferencing, social media technology (Facebook, blackberry messenger, 2go, Twitter, YouTube, Wikipedia), virtual learning environment, the use of iPod, game console, voice projector system, interactive whiteboard, to sophisticated system such as computers, internet, laptops, Personal Digital Assessments (PDAs), radio, television and instructional software. 
The evolution of ICT has resulted in a paradigm shift in the educational system. Information and communication technology is changing the way people learn, offering new alternatives to the traditional classroom. In this new economy, it is essential for learners to have access to education anytime and anywhere. Haddad and Draxler (2012) stated that lifelong learning and training for the workplace cannot be confined to the traditional classroom. It is unrealistic and unaffordable to continue to ask learners to come to a designated place every time they have to engage in learning. ICTs allow the delivery of education to adapt to an individual's needs as opposed to having the individual adapt to how the education is delivered. Education will not be confined to the four walls of a classroom but wherever and whenever the learner deems appropriate. Therefore, with synchronous instructional strategy problem of location and time is resolved.

Disappointingly, it appears that ICTs have made little impact in schools in spite of the seemingly great potential to improve teaching and learning (Miller, 2017). Technology has transformed every segment of the society except education. Schooling today, especially public schooling remains much the same as it was before the advent of personal computers. The lack or inadequate training of teachers is considered to be one of the major barriers for utilization of ICTs in Business Education. Cuneo and Campbell (2010) argued that lack of staff training in ICTs is a major cause of the digital divide among post-secondary institutions. Fletcher and Deeds (2011) indicated that the level of computer literacy of Business Education teachers can decrease computer anxiety and improve attitudes towards computers. The author recommended implementing additional pre-service and in-service ICT training for Business Education teachers.

According to Allen, Walker, and Morehead (2019), many educators are limited in the technological skills needed for successful technology integration in Business Education curriculum due to the lack of recent training in the professional field. There is now a general consensus that teachers are the principal agents for integrating technology in education and training. A study conducted by Jasinski (2008) involving 80 Business Education educators indicated that technology does not improve or cause changes in learning. It is well-designed instructions and how teachers make use of the new capabilities, potentials, and options offered by ICTs that can improve learning significantly. A study conducted by Miller (2017) indicated that only $50 \%$ of teacher education institutions surveyed had implemented a required course in ICTs. The most striking finding of this study was that computers were most frequently being used as "glorified typewriters" in vocational teacher education. Ekanem, Agba and Eminue (2017) argued that Business Educators must know very well the skills being taught and to device a means in the lesson to pass much of the work skills to the learners as possible. The persistent poor representation of students or graduates today has given rise to an assumption that most of the lecturers probably do not make use of some stipulated contemporary teaching strategies that will make students cope with the challenges of learning vocational courses for skill acquisition. 
Perhaps, for effective instructional delivery of Business Educators, there should be a paradigm shift. It is pertinent to note that in the $21^{\text {st }}$ century, teaching of Business Education courses involves more than just using textbooks or a teacher's manual. Ajuzie and Akukwe (2015) observed that teaching and learning process in Business Education in Nigeria is still at the level of "chalk and talk method" which is the traditional method of teaching. It is therefore pertinent to shift from traditional or conventional method to a pragmatic approach such as synchronous online teaching through the use of ICT. Therefore, the focus of this study is on skills need of Business Educators for effective utilization of synchronous instructional strategy in teaching Business Education courses. Skill is the ability to carry out task with pre-determined results often within a given amount of time, energy, or both (Howland, 2013). Skills in the context of this study is an ability, capacity and proficiency of Business Educators to smoothly and adaptively perform a job function. In a dynamic environment, skill is essential for one to be able to meet the challenges of everyday life. Eminue (2018) defined need as what ought to be but is missing and required to be there. Need shows there is something which if present, will better the performance of an individual or group of individuals. Synchronous instructional skills need of Business Educators in the context of this study implies necessity to apply skills related to the use of ICT facilities for real time teaching to achieve the desired educational goal. Business Educators need the word processing, spreadsheet, presentation, chat, video and audioconferencing skills, among others for synchronous teaching. Therefore, the skills need considered in this study are skills related to word processing, spreadsheet and power point presentation.

Word processing is considered one of the most if not the most important skill Business Educators need for effective synchronous learning. Agomuo (2014) asserted that word processing involves the use of advanced hardware to manipulate words, sentences and paragraphs. The word processor emerged with the advent of the electronic typewriters with its ability to manipulate words and sentences in addition to its limited capacity of memory. One of the major features of the word processor according to the author is that the words are typed, and are displayed simultaneously at the Visual Display Unit (VDU). Using computers, there is the enter-key replacing the cursor movement and there are commands (simple ones) or paragraphs, indent and spacing among others. In addition, one can, make corrections to the documents very conveniently and format one's documents to a wide variety of specification.

Nwosu (2003) emphasized that it is important for the teacher to acquire the skills, knowledge and competencies in word processing to be efficient in the performance of their work. Mba (2019) who conducted a study on capacity building needs of business teacher for teaching basic computers in technical colleges in South-East Nigeria found that business studies teachers were proficient in the use of computer key board, use of word processing packages, format document, align text in document, correct spelling, save file names to document, use tools menu as well as view menu to manipulate page layout. Word processing skills are the basic requirement that could enhance effective 
synchronous teaching. Without these skills no synchronous teaching can take, hence Business Educators require word processing skills to be able to provide information and notes in text form to students as fast and accurate as possible.

Spreadsheet skill is another important skill for synchronous teaching of Business Education courses, especially accounting and related subjects. Spreadsheets are integral parts of organizational data analysis activities. In the modern days, individual and organizations are confronted with an increasingly data driven world. An electronic spreadsheet is a computer application that supersedes paper worksheets. Electronic spreadsheet software allows the user to add, subtract, and perform user define calculations on rows or columns and numbers. Miller (2017) opined that Microsoft Excel is a form of an electronic spreadsheet software that eliminates the tedious recalculations required with manual methods. Electronic spreadsheet enables the user to perform data analysis without programming skills. It primarily helps in analysis of numeric data. IbeBassey (2009) stated that electronic spreadsheet is a computer programme that enable people to electronically create and manipulate data in tables of values arranged in rows and columns with predefined relationships to each other. The author further explained that electronic spreadsheets are used for mathematical calculation such as accounts, budgets, statistic among other. Agomuo (2014) noted that an electronic spreadsheet is a matrix of cells into which numbers, text, formulae can be entered, which provide a powerful tool for storing and allowing mathematical calculation to perform easily.

Walter (2017) maintained that acquisition of spreadsheets skills will enable both the teachers and the students to present data sets graphically and also transforms data into charts and graphs of various types which can then be included in presentation. Mba (2019) observed that business studies teachers need capacity building to enable them load MS excel memory, use formula to perform computation, use function key to perform computation, move around worksheet, use toggle within worksheet, edit worksheet, print worksheet, import and export worksheet as well as plot chart. The author noted that the performance gap of business teachers in the identified area of spreadsheet was positive, hence the teachers were recommended to undertake a retraining to bridge the performance gap.

Furthermore, PowerPoint skill is necessary for effective synchronous learning. PowerPoint can house an array of information including graphs, sound effects, video, text, and charts. According to Onwuachu (2014), PowerPoint presentations have become a standard tool for group meetings. Students with these skills are most desired in many private sector offices than those without such skills. Ezinwa (2016) noted that PowerPoint is one of the newest technologies or software that allows teachers and trainers to display their lessons in graphical format to accompany an oral presentation. PowerPoint presentations incorporate graphics, animation, and color (imagery). Odiachi (2019) opined that Power Point software refers to a collection of slides designed to aid the delivery of information to audience. It is an application for presentation that is found in Microsoft Office suit, hence does not require the purchase of separate software for its 
installation. PowerPoint is often used to make handouts, oral presentations, speaker notes, and outlines.

According to Nwosu and Mbaezue (2016), PowerPoint application skills include the ability to open, create and interact with Microsoft PowerPoint, add and delete slide, cut, copy and paste slides and text, use the format painter, use find and replace, add effects and animation, use different methods of savings, close presentation and use help screen for online and offline help. PowerPoint is used for creating presentation for business meetings, schools, projects or creating personal family slideshows. Consequently, the skills of using this application are sorted by business organization and during important public gatherings (Egbunefu, 2018). Dimelu (2010) conducted a study on competency improvement needs of teachers of Home Economics in the use of Information and Communication Technology (ICT) for effective teaching in Home Economics Department in South Eastern Nigeria. The result revealed that, though the teachers of Home Economics have been exposed to ICT training, but the teachers' ICT competence on Internet and PowerPoint usage was still low and this has hindered the home economics teachers' ability on competency improvement needs.

\section{Statement of the Problem}

Business Education programmes are intended to prepare people for gainful employment. In spite of the importance of ICT literacy skills for Business Education teachers, it appears that they are not being adequately prepared to meet the challenge. Odoh (2013) observed that Business Educators still adopt or operate on conventional instructional teaching approach that are mainly lecturers self-centered and not logically sequenced to fit the ability of the learners and what the society needs, as lecturers could not provide opportunity for students' participation in reciprocal teaching of Business subjects leading to persistent poor performance and lack of employment of Business Education graduate. Could this be because Business Educators do not acquire skills needed for utilization of synchronous online instruction or the level of skills acquired is not adequate? The quest to answer this question motivated the researchers to undertake this study to determine skills need of Business Educators for utilisation of synchronous instructional strategy in teaching Business Education courses in Colleges of Education in South-South Nigeria.

\subsection{Purpose of the Study}

The main purpose of the study was to determine skills need of Business Educators for utilisation of synchronous instructional strategy in teaching Business Education courses in Colleges of Education in South-South Nigeria. Specifically, the study sought to determine;

1) Word processing skills need of Business Educators for utilisation of synchronous instructional strategy in teaching Business Education courses in Colleges of Education in South-South Nigeria. 
2) Spreadsheet skills need of Business Educators for utilisation of synchronous instructional strategy in teaching Business Education courses in Colleges of Education in South-South Nigeria.

3) PowerPoint skills need of Business Educators for utilisation of synchronous instructional strategy in teaching Business Education courses in Colleges of Education in South-South Nigeria.

\subsection{Research Questions}

The following research questions were raised to guide the study.

1) What are the word processing skills need of Business Educators for utilisation of synchronous instructional strategy in teaching Business Education courses in Colleges of Education in South-South Nigeria?

2) What are the spreadsheet skills need of Business Educators for utilisation of synchronous instructional strategy in teaching Business Education courses in Colleges of Education in South-South Nigeria?

3) What are the PowerPoint skills need of Business Educators for utilisation of synchronous instructional strategy in teaching Business Education courses in Colleges of Education in South-South Nigeria?

\subsection{Research Hypothesis}

The following hypothesis were formulated and tested at 0.05 level of significance. Ho1: There is no significant difference in the mean rating of Computer Education lecturers and Business Educators on word processing skills need of Business Educators for utilisation of synchronous instructional strategy in teaching Business Education courses in Colleges of Education in South-South Nigeria.

Ho2: There is no significant difference in the mean rating of Computer Education lecturers and Business Educators on spreadsheet skills need of Business Educators for utilisation of synchronous instructional strategy in teaching Business Education courses in Colleges of Education in South-South Nigeria.

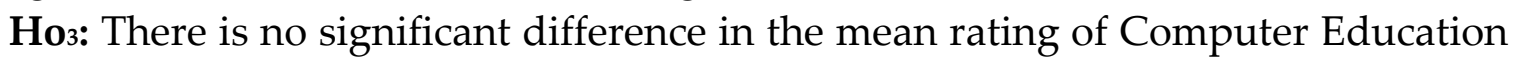
lecturers and Business Educators on PowerPoint skills need of Business Educators for utilisation of synchronous instructional strategy in teaching Business Education courses in Colleges of Education in South-South Nigeria.

\section{Research Method}

This study adopted a descriptive survey research design. Descriptive survey research design permits the collection of data through the use of questionnaire from a sample of a defined population for opinion survey. The design was considered suitable since information on skills need were collected from a sample of Computer Education lecturers and Business Educators using questionnaire. The study was carried out in South-South 
Nigeria. The South-South is also known as the Niger Delta Oil Zone, which is made up of six States, namely; Akwa Ibom, Bayelsa, Cross River, Delta, Edo and Rivers States. One of the things the six States have in common is that they are the keys to the Nigeria economy. Most of the oil wells are located in this region. South-South Nigeria provides the economic mainstream of the country. The Zone has both Federal and State Colleges of Education. The choice of this area was because of perceived relevance of Business Education in the development of the potentials of the zone. Skills in utilization of synchronous instructional strategy would reposition Business Education for the development of South-South Nigeria.

The population of the study was 276 respondents made up of 164 Business Educators and 112 Computer Education lecturers from 10 State Colleges of Education in South-South Nigeria. the sample of the study was 163 respondents made up of 97 Business Educators and 66 Computer Education lecturers from 10 State Colleges of Education in South-South Nigeria. The sample was determined using Taro Yamane formulae. The sampling frame of $59 \%$ was used to ensure even representation of the respondents, while convenient sampling technique was adopted to select respondents who were available and accessible for the study.

The researcher developed instrument titled Skills Need for Utilisation of Synchronous Instructional Strategy Questionnaire (SNUSIS) was used to obtain data for the study. The instrument has two sets of respond options - one for Business Educators and the other for the Computer Education lecturers. The responses were made on a 4point rating scale as follows:

\begin{tabular}{|l|c|c|}
\hline Computer Education Lecturers & Business Educators & Value \\
\hline Very Highly Needed (VHN) & Very Highly Possessed (VHP) & 4 \\
\hline Highly Needed (HN) & Highly Possessed (HP) & 3 \\
\hline Lowly Needed (LN) & Low Possessed (LP) & 2 \\
\hline Very Lowly Needed (VLN) & Very Low Possessed (VLP) & 1 \\
\hline
\end{tabular}

The instrument was face validated by three research experts, two experts in Business Education Department and one in Computer Education Department, all in University of Uyo, Akwa Ibom State, Nigeria. Corrections and adjustment were made before embarking on the field work. The internal consistency reliability of the instrument was determined using Cronbach Alpha. A reliability coefficient of 0.81 was obtained. The high reliability index made the instruments suitable for the study. The data collected were analysed using Mean to answer the research questions, the difference between the Mean rating of Computer Education lecturers and Business Educators was determined through an Improvement Need Index (INI), while hypotheses were tested using t-test at 0.05 level of significance. The Statistical Package for Social Science (SPSS) was used to analyze the data. 


\section{Results}

Research Question 1: What are the word processing skills need of Business Educators for utilisation of synchronous instructional strategy in teaching Business Education courses in Colleges of Education in South-South Nigeria?

Table 1: Performance Gap Analysis of Mean Responses of

Business Educators in Word Processing Skills $(n=163)$

\begin{tabular}{|c|l|c|c|c|c|}
\hline $\mathbf{S} / \mathbf{N}$ & Word Processing Skills & $\overline{\boldsymbol{X}}_{\mathbf{N}}$ & $\overline{\boldsymbol{X}}_{\mathbf{P}}$ & $\overline{\boldsymbol{X}}_{\mathbf{N}}-\overline{\boldsymbol{X}}_{\mathbf{P}}$ & Remarks \\
\hline 1 & Ability to create text & 3.54 & 3.75 & -0.21 & SNN \\
\hline 2 & Ability to adjust line spacing & 3.52 & 3.61 & -0.04 & SNN \\
\hline 3 & Ability to format document & 3.74 & 3.49 & 0.25 & SN \\
\hline 4 & Ability to insert headers & 3.56 & 3.57 & -0.01 & SNN \\
\hline 5 & Ability to insert tables & 3.62 & 3.68 & -0.06 & SNN \\
\hline 6 & Ability to draw shapes & 3.69 & 3.64 & 0.05 & SN \\
\hline 7 & Ability to spell check a document & 3.48 & 3.55 & -0.07 & SNN \\
\hline 8 & Bookmarking a location to document & 3.63 & 3.56 & 0.07 & SN \\
\hline 9 & Ability to use tools menu & 3.63 & 3.73 & -0.10 & SNN \\
\hline 10 & Ability to insert page number & 3.56 & 3.69 & -0.13 & SNN \\
\hline & Grand Mean & $\mathbf{3 6 . 0 8}$ & 36.27 & $\mathbf{- 0 . 1 9}$ & SNN \\
\hline
\end{tabular}

Key: SN = Skills Needed; SNN = Skills Not Needed; Source: Field Work (2021)

The data presented in Table 1 indicated that items 3, 6 and 8 on word processing skills have their performance gap to be positive (0.05-0.25). The result implies that Business Educators need more training on formatting of document, drawing of shapes and bookmarking of location in a document. The result also indicated that the remaining seven items and overall Mean have their performance gap to be negative (-0.01 to -0.19). This implies that word processing skills are not needed by Business Educators for utilisation of synchronous instructional strategy in teaching Business Education courses in Colleges of Education in South-South Nigeria. The significance of the result is tested in Table 2.

Ho1: There is no significant difference in the Mean rating of Computer Education Lecturers and Business Educators on the word processing skills need of Business Educators for utilisation of synchronous instructional strategy in teaching Business Education courses in Colleges of Education in South-South Nigeria.

Table 2 gives the summary of the t-test analysis of the difference in the Mean rating of Computer Education Lecturers and Business Educators in word processing skills needs for utilisation of synchronous instructional strategy in teaching Business Education courses in Colleges of Education in South-South Nigeria. The result shows that the calculated $t$-value is 0.67 and p-value 0.91 at 161 degree of freedom. Since the p-value is greater than the 0.05 alpha level, it implies there is no significant difference between the mean rating of the respondents hence, the research hypothesis which stated that there is 
no significant difference in the Mean rating of Computer Education Lecturers and Business Educators in word processing skills need for utilisation of synchronous instructional strategy in teaching Business Education courses in Colleges of Education in South-South Nigeria is retained.

Table 2: t-test analysis on the difference in the Mean rating of

Computer Education Lecturers and Business Educators in word processing skills needs for utilization of synchronous instructional strategy

\begin{tabular}{|l|c|c|c|c|c|c|c|}
\hline Groups & $\mathbf{n}$ & $\overline{\boldsymbol{X}}$ & SD & DF & t-cal & p-value & Decision \\
\hline Computer Lecturers & 66 & 36.08 & 1.59 & \multirow{2}{*}{161} & 0.67 & \multirow{2}{*}{091} & \multirow{2}{*}{ NS } \\
\cline { 1 - 5 } Business Educators & 97 & 36.27 & 1.72 & & & & \\
\hline
\end{tabular}

Note: NS = Not Significant, Sig@ $@ 0.05$ Source: Field Work (2021)

Research Question 2: What are the spreadsheet skills need of Business Educators for utilisation of synchronous instructional strategy in teaching Business Education courses in Colleges of Education in South-South Nigeria?

Table 3: Performance Gap Analysis of Mean Responses of Business Educators in Spreadsheet Skills $(n=163)$

\begin{tabular}{|c|l|c|c|c|c|}
\hline S/N & Spreadsheet Skills & $\overline{\boldsymbol{X}}_{\mathbf{N}}$ & $\overline{\boldsymbol{X}}_{\mathbf{P}}$ & $\overline{\boldsymbol{X}}_{\mathbf{N}}-\overline{\boldsymbol{X}}_{\mathbf{P}}$ & Remarks \\
\hline 1 & Ability to plot graphs & 3.74 & 3.41 & 0.34 & SN \\
\hline 2 & Ability to format cells & 3.46 & 3.23 & 0.23 & SN \\
\hline 3 & Editing of cells & 3.42 & 3.24 & 0.18 & SN \\
\hline 4 & Ability to transform data & 3.59 & 3.36 & 0.23 & SN \\
\hline 5 & Statistical analysis of data & 3.52 & 3.29 & 0.28 & SN \\
\hline 6 & Ability to calculate using Autosum & 3.40 & 3.52 & -0.12 & SNN \\
\hline 7 & Ability to calculate using formulas & 3.46 & 3.35 & 0.11 & SN \\
\hline 8 & ability to define a name for a cell & 3.57 & 3.52 & 0.05 & SN \\
\hline 9 & Ability to insert column & 3.57 & 3.54 & 0.03 & SN \\
\hline 10 & Ability to insert row & 3.59 & 3.58 & 0.01 & SN \\
\hline & Grand mean & $\mathbf{3 5 . 3 7}$ & $\mathbf{3 4 . 0 4}$ & $\mathbf{1 . 3 3}$ & SN \\
\hline
\end{tabular}

Key: SN = Skill Needed; SNN = Skill Not Needed; Source: Field Work (2021)

The data presented in Table 3 indicated that all the items on spreadsheet skills and overall Mean have their performance gap to be positive (0.01-1.33), except item 6 with a negative performance gap (-0.12). The result implies that Business Educators need more spreadsheet skills for utilisation of synchronous instructional strategy in teaching Business Education courses in Colleges of Education in South-South Nigeria. The significance of the result is tested in Table 4.

Hoz: There is no significant difference in the Mean rating of Computer Education Lecturers and Business Educators on the spreadsheet skills need of Business Educators for utilisation of synchronous instructional strategy in teaching Business Education courses in Colleges of Education in South-South Nigeria. 
Nsini A. Akpan, Uduonyi O. Eminue, Juliet O. Onyebueke, Dominic E. Ogbang SKILLS NEED OF BUSINESS EDUCATORS FOR UTILISATION OF SYNCHRONOUS INSTRUCTIONAL STRATEGY IN TEACHING BUSINESS EDUCATION COURSES IN COLLEGES OF EDUCATION IN SOUTH-SOUTH NIGERIA

Table 4: t-test analysis on the difference in the Mean Rating of Computer Education Lecturers and Business Educators in spreadsheet skills need for utilization of synchronous instructional strategy

\begin{tabular}{|l|c|c|c|c|c|c|c|}
\hline Groups & $\mathbf{n}$ & $\overline{\boldsymbol{X}}$ & SD & DF & t-cal & p-value & Decision \\
\hline Computer Lecturers & 66 & 35.27 & 1.60 & \multirow{2}{*}{161} & \multirow{2}{*}{3.78} & .000 & $\mathrm{~S}$ \\
\hline Business Educators & 97 & 34.04 & 2.52 & & & & \\
\hline
\end{tabular}

Note: $\mathrm{S}=$ Significant, Sig@p $\leq .05$ Source: Field Work (2021)

Table 4 gives the summary of the t-test analysis of the difference in the Mean rating of Computer Education Lecturers and Business Educators in spreadsheet skills needs for utilisation of synchronous instructional strategy in teaching Business Education courses in Colleges of Education in South-South Nigeria. The result shows that the calculated tvalue is 3.78 and p-value is .000 at 161 degree of freedom. Since the p-value is lower than the 0.05 alpha level, it implies there is a significant difference between the mean of the respondents hence, the research hypothesis which stated that there is no significant difference in the Mean rating of Computer Education Lecturers and Business Educators in spreadsheet skills need for utilisation of synchronous instructional strategy in teaching Business Education courses in Colleges of Education in South-South Nigeria is rejected.

Research Question 3: What are the PowerPoint skills need of Business Educators for utilisation of synchronous instructional strategy in teaching Business Education courses in Colleges of Education in South-South Nigeria?

Table 5: Performance Gap Analysis of Mean Responses of Business Educators in PowerPoint Skills $(n=163)$

\begin{tabular}{|c|l|c|c|c|c|}
\hline $\mathbf{S} / \mathbf{N}$ & PowerPoint Skills & $\overline{\boldsymbol{X}}_{\mathbf{N}}$ & $\overline{\boldsymbol{X}}_{\mathbf{P}}$ & $\overline{\boldsymbol{X}}_{\mathbf{N}}-\overline{\boldsymbol{X}}_{\mathbf{P}}$ & Remarks \\
\hline 1 & Creating slides & 3.59 & 3.40 & 0.19 & SN \\
\hline 2 & Recording slide show & 3.48 & 3.21 & 0.27 & SN \\
\hline 3 & Adding object to slide & 3.56 & 3.52 & 0.04 & SN \\
\hline 4 & Designing slides & 3.67 & 3.31 & 0.36 & SN \\
\hline 5 & Ability to zoom object & 3.41 & 3.39 & 0.02 & SN \\
\hline 6 & Ability to change slide view & 3.61 & 3.59 & 0.02 & SN \\
\hline 7 & Ability to edit object in slide & 3.45 & 3.38 & 0.07 & SN \\
\hline 8 & Ability to transit from slide to slide & 3.37 & 3.38 & -0.01 & SNN \\
\hline 9 & Adding animation to object & 3.66 & 3.43 & 0.23 & SN \\
\hline 10 & Deleting animation from object & 3.51 & 3.35 & 0.16 & SN \\
\hline & Grand Mean & $\mathbf{3 5 . 3 1}$ & $\mathbf{3 3 . 9 6}$ & $\mathbf{1 . 3 5}$ & SN \\
\hline
\end{tabular}

Key: SN = Skill Needed; SNN = Skill Not Needed; Source: Field Work (2021)

The data presented in Table 5 indicated that all the items on PowerPoint skills and overall Mean have their performance gap to be positive (0.02-1.35), except item 8 with a negative performance gap (-0.01). The result implies that Business Educators need more PowerPoint skills for utilisation of synchronous instructional strategy in teaching 
Business Education courses in Colleges of Education in South-South Nigeria. The significance of the result is tested in Table 6.

Ноз: There is no significant difference in the Mean rating of Computer Education Lecturers and Business Educators on the PowerPoint skills need of Business Educators for utilisation of synchronous instructional strategy in teaching Business Education courses in Colleges of Education in South-South Nigeria.

Table 6: t-test analysis on the difference in the Mean Rating of Computer Education Lecturers and Business Educators in PowerPoint

skills need for utilization of synchronous instructional strategy

\begin{tabular}{|l|c|c|c|c|c|c|c|}
\hline Groups & $\mathbf{n}$ & $\overline{\boldsymbol{X}}$ & SD & DF & t-cal & p-value & Decision \\
\hline Computer Lecturers & 66 & 35.31 & 1.63 & \multirow{2}{*}{161} & \multirow{2}{*}{3.48} & \multirow{2}{*}{000} & $\mathrm{~S}$ \\
\hline Business Educators & 97 & 33.96 & 2.79 & & & & \\
\hline
\end{tabular}

Note: S = Significant, Sig@p $\leq .05$ Source: Field Work (2021)

Table 6 gives the summary of the t-test analysis of the difference in the Mean rating of Computer Education Lecturers and Business Educators in PowerPoint skills needs for utilisation of synchronous instructional strategy in teaching Business Education courses in Colleges of Education in South-South Nigeria. The result shows that the calculated tvalue is 3.48 and p-value is .000 at 161 degree of freedom. Since the p-value is lower than the 0.05 alpha level, it implies there is a significant difference between the mean of the respondents hence, the research hypothesis which stated that there is no significant difference in the Mean rating of Computer Education Lecturers and Business Educators in PowerPoint skills need for utilisation of synchronous instructional strategy in teaching Business Education courses in Colleges of Education in South-South Nigeria is rejected.

\section{Discussion of Findings}

The result of the first research question on word processing skills revealed that Business Educators need more training on formatting of document, drawing of shapes and bookmarking of location in a document. This is because the performance gaps of these items indicated positive, meaning the level of the skills acquired by Business Educators are lower than the expected benchmark by the Computer Education lecturers. The result also indicated that Business Educators do not need more training on creating text, adjusting line spacing, inserting headers, inserting tables, spell checking a document, using tool menu and inserting page numbers. This is because the performance gap indicated negative, which implies the level of skills acquired by Business Educators in these areas are higher than the expected benchmark. The corresponding hypothesis revealed that there is no significant difference between the mean rating of the respondents hence, the research hypothesis which stated that there is no significant difference in the Mean rating of Computer Education Lecturers and Business Educators in word processing skills need for utilisation of synchronous instructional strategy in 
teaching Business Education courses in Colleges of Education in South-South Nigeria is retained. This result is in line with the finding of Mba (2019) who conducted a study on capacity building needs of business teacher for teaching basic computers in technical colleges in South-East Nigeria and found that business studies teachers were proficient in the use of computer key board, use of word processing packages, format document, align text in document, correct spelling, save file names to document, use tools menu as well as view menu to manipulate page layout.

The result of the second research question on spreadsheet skills revealed that Business Educators need more training on plotting of graphs, formatting cells, editing cells, transforming data, statistical analysis of data, calculating using formulas, defining name for a cell, inserting column and inserting row. This is because the performance gaps of these items indicated positive, meaning the level of the skills acquired by Business Educators are lower than the expected benchmark by the Computer Education lecturers. The result also indicated that Business Educators do not need more training on calculation using AutoSum. This is because the performance gap indicated negative, which implies the level of skills acquired by Business Educators is higher than the expected benchmark. The corresponding hypothesis revealed that there is a significant difference between the mean rating of the respondents hence, the research hypothesis which stated that there is no significant difference in the Mean rating of Computer Education Lecturers and Business Educators in spreadsheet skills need for utilisation of synchronous instructional strategy in teaching Business Education courses in Colleges of Education in South-South Nigeria is rejected. This result is in line with the finding of $\mathrm{Mba}$ (2019) who observed that business studies teachers need capacity building to enable them load MS excel memory, use formula to perform computation, use function key to perform computation, move around worksheet, use toggle within worksheet, edit worksheet, print worksheet, import and export worksheet as well as plot chart.

The result of the third research question on PowerPoint skills revealed that Business Educators need more training on creating slides, recording slide show, adding object to the slide, designing slides, zooming object, changing slide view, editing object in the slide, adding animation to object and deleting animation from object. This is because the performance gaps of these items indicated positive, meaning the level of the skills acquired by Business Educators are lower than the expected benchmark by the Computer Education lecturers. The result also indicated that Business Educators do not need more training on transition from slide to slide. This is because the performance gap indicated negative, which implies that the level of skills acquired by Business Educators is higher than the expected benchmark. The corresponding hypothesis revealed that there is a significant difference between the mean rating of the respondents hence, the research hypothesis which stated that there is no significant difference in the Mean rating of Computer Education Lecturers and Business Educators in PowerPoint skills need for utilisation of synchronous instructional strategy in teaching Business Education courses in Colleges of Education in South-South Nigeria is rejected. This result is in line with the 
finding of Dimelu (2010) who revealed that, though the teachers of Home Economics have been exposed to ICT training, but the teachers' ICT competence on Internet and PowerPoint usage was still low.

\section{Conclusion}

In conclusion, the results of the study showed that, for utilisation of synchronous instructional strategy in teaching Business Education courses in Colleges of Education in South-South Nigeria, Business Educators need more training on word processing in the area of formatting of document, drawing of shapes and bookmarking of location in a document, while no training is needed in creating text, adjusting line spacing, inserting headers, inserting tables, spell checking a document, using tool menu and inserting page numbers. The result also showed that Business Educators need more training on spreadsheet in the area of plotting of graphs, formatting cells, editing cells, transforming data, statistical analysis of data, calculating using formulas, defining name for a cell, inserting column and inserting row. The result further indicated that Business Educators need more training on PowerPoint in the area of creating slides, recording slide show, adding object to the slide, designing slides, zooming object, changing slide view, editing object in the slide, adding animation to object and deleting animation from object. It is therefore important to expose Business Educators to more training on the identified skills with positive performance gap for effective utilisation of synchronous instructional strategy in teaching Business Education courses in Colleges of Education in South-South Nigeria.

\section{Recommendations}

Based on the findings and the conclusion of the study it is recommended that;

- Management of Colleges of Education should provide opportunity for Business Educators to undertake more training on word processing, spreadsheet and PowerPoint through Seminars, workshops and conferences to enhance their ability to utilise synchronous instructional strategy in teaching Business Education courses in Colleges of Education in South-South Nigeria.

- Synchronous learning should be integrated into Business Education curriculum by curriculum developers to motivate Business Educator to seek training to acquire skills for effective utilization in teaching Business Education courses in Colleges of Education in South-South Nigeria.

\section{Conflict of Interest Statement}

The authors declare no conflicts of interests. 


\section{About the Authors}

Nsini A. Akpan (PhD) is an Associate Professor and the Head of Department of Business Education, Faculty of Education, University of Uyo, Nigeria. He is a holder of NCE, BSc (Ed), M (Ed), PhD (Uyo) and some professional certificates. He is a registered member of Teachers Registration Council of Nigeria (TRCN), Association of Business Educators of Nigeria (ABEN) and Knight of Saint John International (KSJI). Akpan has authored several Journal articles,

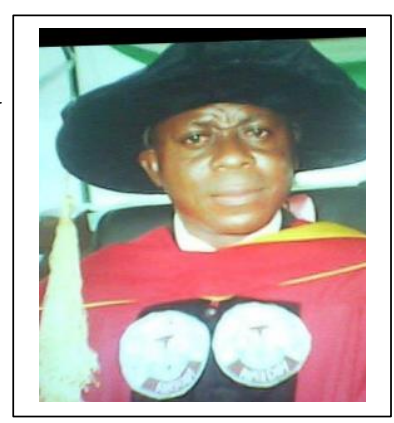
book chapters and conference/seminar papers circulating within and outside Nigeria. His research interest covers Entrepreneurship Education, Office Technology and Management Education (OTME), trend and issues in Business Education, as well as administration and supervision of Vocational Education. He is a husband of one wife and four children.

Uduonyi O. Eminue is a Teacher with Akwa Ibom State Universal Basic Education Board. He is a holder of NCE (Afaha Nsit), BSc (Ed) (Calabar), MSc (Ed) (Uyo). He is currently a doctoral candidate, Department of Business Education, Faculty of Education, University of Uyo, Akwa Ibom State, Nigeria. He is a member of International Forum of Educational Benchmarkers (IFEB), Teachers Registration Council of Nigeria (TRCN) and Association of Business Educators of Nigeria (ABEN). Eminue has authored and coauthored some book chapters, conference/seminar papers and articles in both national and international journals. His research interest covers Accounting, Management and Marketing, as well as emerging issues in Business Education. He is happily married to Mrs. Mary U. Eminue.

Juliet O. Onyebueke is an Admin Stsff of Haraform and Chemicals Limited, Kuchikau, Nasarawa State, Nigeria. She is a holder of BSc (Ed) in Business Education from Nnamdi Azikiwe University, Awka Anambra State, Nigeria. He is currently a Master Degree student, Department of Business Education, Faculty of Education, University of Uyo, Akwa Ibom State, Nigeria. She is a registered member of Teachers Registration Council of Nigeria (TRCN) and International

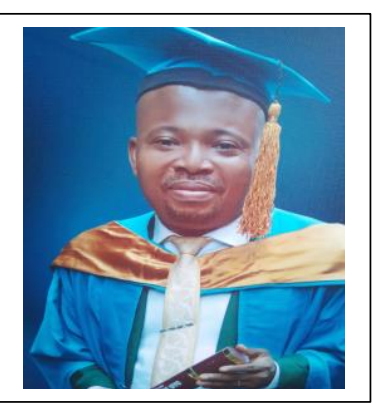
Forum of Educational Benchmarkers (IFEB). She is a mother of a son. Dominic E. Ogbang is a native of Ukpada in Utugwang, Obudu Local Government Area, Cross River State, Nigeria. He is a holder of NCE (Obudu) and BSc (Ed) in Business Education from Cross River State University of Technology. He is currently a Master Degree student, Department of Business Education, Faculty of Education, University of Uyo, Akwa Ibom State, Nigeria. Ogbang is a Business Educator

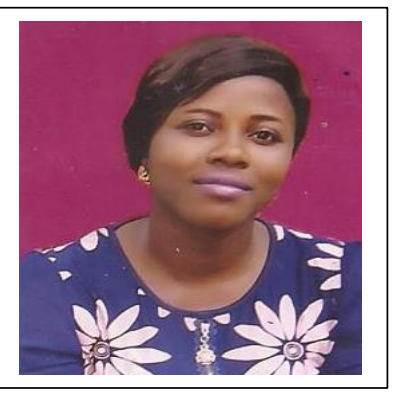
who specilises in Management. He is a registered member of Teachers Registration Council of Nigeria (TRCN) and Nigeria Institute of Management (NIM). 


\section{References}

Agomuo, E. E. (2014). Modern office technology, issues, procedures and practice. Debees Printing Services, 119p.

Ajuzie, N. E. and Akukwe, A. C. (2015). An Assessment of the Use of ICT Tools by Students to the Study of Business Education. World Scientific News. 9(1), 9-17.

Akpan, N. A. and Eminue, U. O. (2020). Facility planning issues in Business Education: Implication for combating unemployment and youth restiveness in Nigeria. Nigerian Journal of Business Education (NIGJBED), 7(1): 458-471.

Allen, J., Walker, M. \& Morehead, C. (2019). Technology in secondary career and technical education: Issues for the new millennium. Workforce Education Forum, 26(1): 1-13.

Asuquo, E. E. (2016). Element of vocational business education. In: E. O. Uko, C. I. Ugbaja, V. S. O. Ibe and J. C. Obunadike (Ed). Foundation of Technical Vocational Education and Training (TVET). IGM Ventures Publisher, Uyo, Nigeria, pp109-118.

Asuquo, E. E. and Usip, M. E. (2016). Capacity building needs of business teachers in teaching methodology and instructional materials selections for teaching of business subjects in senior secondary school in Akwa Ibom State. International Journal of Educational Benchmark, 5(4): 108 - 123.

Cuneo, C., and Campbell, B. (2010). Changes in Canadian higher education ICT and support, 2000-2003. Paper presented to EDMEDIA 2000 World Conference on Educational Multimedia, Hypermedia and Telecommunications, Montreal, QC, June 29.

Dimelu, I. N. (2010). Competency - improvement needs teachers of Home Economics in the use of ICT for effective teaching in colleges of education in South Eastern Nigeria. Journal of Nigerian Vocational Association, 14(2):17 - 25.

Egbunefu, C. (2018). Information systems application skills need of secretaries for job performance in public parastatals in Rivers State. A thesis submitted to the Department of Vocational Education, University of Uyo for the award of $\mathrm{PhD}$ Business Education.

Ekanem, M. N., Agba, P. I. \& Eminue, U. O. (2017). Skills training need of TVET lecturers in scaffolding technique for teaching vocational subjects in college of education Afaha Nsit. Journal of Educational Realities-JERA, 4(1): 38-48.

Eminue, U. O. (2018). Selected skills need of fish distributors for enhanced fish market in Akwa Ibom State. A Masters Dissertation, Department of Business Education, University of Uyo, Nigeria. 118p.

Eminue, U. O., Garba, A. \& Njoku, C. I. (2020). Adoption of synchronous instructional strategy and students' academic performance in Accounting in secondary schools in Akwa Ibom State, Nigeria. European Journal of Education Studies, 7(1): 265-276.

Etifit, P. A., Eminue, U. O. \& Udoh, I. E. (2016). ICT and accounting skills required for the establishment of small scale enterprises by business education students in College of Education, Afaha Nsit, Akwa Ibom State. International Journal of Educational Benchmark, 5(1): 57-71. 
Ezinwa, B. A. (2016). PowerPoint presentation as an alternative to traditional approach to teaching Business Education courses in tertiary institutions: benefits, challenges and solution. Nigerian Journal of Business Education, 3(2), 1-13.

Fletcher, W. E., and Deeds, J. P. (2011). Factors preventing microcomputer use among secondary agriculture education teachers in the United States. Proceedings of the Eighteenth Annual National Agricultural Education Research Meeting, (pp. 229-237). Los Angeles.

Haddad, W. D. and Draxler, A. (2012). The Dynamics of Technologies for Education. In W. D. Haddad \& A. Draxler (Eds.), Technologies for Education Potentials, Parameters, and Prospects, 1. (pp. 2-17). Prepared for UNESCO and AED by Knowledge Enterprise Inc.

Higley M. (2013). Benefits of synchronous and asynchronous e-learning. Available at: https://elearningindustry.com/benefits-of-synchronous-and-asynchronouselearning. Retrieved on November 3, 2019.

Howland, J. L. (2013). Facts 101: Text book key facts. Contents Technology Inc. Available at: https://en.m.wikipedia.org/wiki/skill. (Retrieved on January 28, 2021).

Ibe-Bassey, G. S. (2009). Technology learning principles for pre-service and in service teacher education. Contemporary Issues in Technology and teacher education, 4(3):345 $-362$

Jasinski, M. (2008). Teaching and learning style that facilitate online learning: Documentation project, project report. Douglas Mawson Institute of TAFE, Adelaide.

LeShea, A. V. (2013). The effects of synchronous class sessions on students' academic achievement and levels of satisfaction in an online introduction to computers course. An unpublished PhD Thesis, Lanier Technical College Faculty, Liberty University, Lynchburg VA.

Mba, R. N. (2019). Capacity building needs of business studies teachers for teaching basic computer skills in Technical Colleges in South-East, Nigeria. A PhD Thesis, Department of Business Education, University of Uyo, Nigeria. 192p.

Miller, L. W. (2017). Computer integration by vocational teachers. Journal of Vocational and Technical Education 14(1). Retrieved January 2, 2021, from http://scholar.lib.vt.edu/ejournals/JVTE/v14n1/JVTE-3.html

Nwosu, A. A. (2003). Integrating ICT into STM classroom: Status and implications. Proceedings of the 44th Science Teachers Association of Nigeria Conference, pp. 5860.

Nwosu, B. O. and Mbaezue, A. N. (2016): PowerPoint competencies required of office technology and management lecturers in south-east geopolitical zone of Nigeria for efficient adaptation of the emerging methodologies: Nigerian Journal of Business Education: 3 (1): 205 - 215.

Odiachi, B. (2019). Availability and utilization of e-learning resources for teaching and learning of office technology and management courses in polytechnics in Delta State. Association of Business Educators of Nigeria (ABEN), 661-671. 
Odoh, C. O. (2013). Effects of Brainstorming on Students' Achievement in Senior Secondary Chemistry. Journal of Qualitative Education, 9(4): 66 - 73.

Onwuachu, R. N. (2014). Producing global workers through Business Education programme using computer and ICT skills. Nigerian Journal of Business Education. 2(1). 241 - 249.

Walter, E. (2017). Computer viruses: The technology and evolution. McGraw-Hill Company, New York, 890p. 
Nsini A. Akpan, Uduonyi O. Eminue, Juliet O. Onyebueke, Dominic E. Ogbang to copy, distribute, transmit or adapt the article content, providing a proper, prominent and unambiguous attribution to the authors in a manner that makes clear that the materials are being reused under permission of a Creative Commons License. Views, opinions and conclusions expressed in this research article are views, opinions and conclusions of the author(s). Open Access Publishing Group and European Journal of Education Studies shall not be responsible or answerable for any loss, damage or liability caused in relation to/arising out of conflicts of interest, copyright violations and inappropriate or inaccurate use of any kind content related or integrated into the research work. All the published works are meeting the Open Access Publishing requirements and can be freely accessed, shared, modified, distributed and used in educational, commercial and non-commercial purposes under a Creative Commons Attribution 4.0 International License (CC BY 4.0). 